\title{
Molecular Marker Based Characterization and Genetic Diversity Analysis of Rice Using SSR and RAPD
}

\author{
A. Q. Khan ${ }^{1}$, H. Huq ${ }^{2 *}$ and M. S. A. Sarker ${ }^{3}$ \\ ${ }^{1}$ Dept. of Biotechnology, Bangladesh Agricultural University, Mymensingh (22 02), Bangladesh \\ ${ }^{2}$ Dept. of Biotechnology, Sher-e-Bangla Agricultural University, Sher-e-Bangla Nagar, Dhaka (12 07), Bangladesh \\ ${ }^{3}$ School of Agriculture and Rural Development, Bangladesh Open University, Gazipur (17 05), Bangladesh
}

\section{Article History}

Manuscript No. AR866

Received in $26^{\text {th }}$ July, 2014

Received in revised form $6^{\text {th }}$ April, 2015

Accepted in final form $26^{\text {th }}$ May, 2015

\section{Correspondence to}

*E-mail:muna_sau@yahoo.com

\section{Keywords}

Molecular marker, SSR, RAPD, genetic diversity, rice

\begin{abstract}
Twenty diverse rice germplasm were used to estimate genetic diversity using five microsatellites (SSR) and five randomly amplified polymorphic DNA (RAPD) markers. A total of 33 clear and repeatable bands were scored from RAPD markers and 33 alleles were detected from SSR primer pairs. Average polymorphic information content (PIC) value across the SSR alleles was 0.789 and average polymorphism for all microsatellite markers was $100 \%$. Polymorphism level revealed by RAPD was $93.80 \%$. The unweighted pair group method of arithmetic means (UPGMA) dendrogram on Nei's genetic distance based on SSR markers clubbed germplasms into three clusters: Binadhan-5, Binadhan-6, Iratom-24, BRRI Dhan 37 and BRRI Dhan 36 in cluster 1; TNDB-100, Binashail, Chini Shagor, BRRI Dhan 41, RD-2586, Jongli Boro, BRRI Dhan-40 and Kalo Bhog formed cluster 2; and Dhol Kochuri, BINA Dhan-4, BRRI Dhan 38, Y-1281, Baowi Jhak, BRRI Dhan 32 and Kala Jira formed cluster 3. The UPGMA dendrogram on Nei's genetic distance based on RAPD markers clustered germplasms into three clusters: BRRI Dhan 37, Iratom-24, BRRI Dhan 36, Binashail, RD-2586, BRRI Dhan 32, TNDB-100, BRRI Dhan 40 and Kala Jira were grouped in cluster 1; BRRI Dhan 38, BRRI Dhan 41, Chini Shagor, Baowi Jhak and Kalo Bhog were grouped in cluster 2; and Jongli Boro 581, BINA Dhan-4, BINA Dhan-5, BINA Dhan-6, Y-1281 and Dhol Kochuri were grouped in cluster 3. Both SSR and RAPD markers revealed BINA Dhan-5 and BINA Dhan-6 with lowest genetic diversity between them. SSR analysis showed more definite separation of clusters of genotype indicating a higher level of efficiency of these markers in determining relationships between germplasms than RAPD markers.
\end{abstract}

\section{Introduction}

Rice is grown under diverse cultural conditions and over wide geographical range. In Bangladesh, rice varieties have been developed traditionally by selection, hybridization and backcrossing with locally adapted high-yielding lines. The number of parental lines used in the breeding programmes is however quite small, resulting in a narrow genetic base. Genetic uniformity in crops can be undesirable in terms of vulnerability of the crop to epidemics and environmental stresses.

Genetic diversity is commonly measured by genetic distance or genetic similarity (Weir, 1990). Molecular markers provide information that can help to define the distinctiveness of germplasm and their ranking according to the number of close relatives and their phylogenetic position which helps to identify and develop genetically unique germplasm that compliments existing cultivars. Availability of a large number of polymorphic markers enables precise classification of the cultivars. Several molecular markers viz. RFLP (Becker et al., 1995), RAPD (Williams et al., 1990), SSRs (Levinson and Gutman, 1987), ISSRs (Blair et al., 1999), and AFLP (Zhu et al., 1998) are presently available to assess the variability and diversity at molecular level (Joshi et al., 2000). SSR has been successfully used to construct detailed genetic maps of several organisms and to study genetic variation within populations of the same species such as rice (Brown et al., 1996). Based on the study large number range of similarity values for related rice cultivars using SSR markers provides greater confidence for the assessment of genetic diversity and relationships (Chakravarthi and Naravaneni, 2006). Random Amplified Polymorphic DNA (RAPD) is the a widely used 
molecular marker where DNA fragments are amplified by the polymerase chain reaction (PCR) using short (usually 10 bases in length) synthetic primers of random sequence. RAPD markers tend to estimate intra or inter genetic distances more distantly related individuals. Hence, present investigation was to assess genetic diversity among 20 rice germplasms using SSR and RAPD markers.

\section{Materials and Methods}

The study was carried out with six landraces, three advanced mutants and 11 high yielding rice varieties obtained from International Rice Research Institute (IRRI), Philippines, Bangladesh Institute of Nuclear Agriculture (BINA) and Bangladesh Rice Research Institute (BRRI).

\subsection{DNA extraction}

DNA was extracted from rice leaves using the modified mini preparation CTAB method (IRRI, 1997).

\subsection{SSR Analysis}

SSR primers RM231, RM24, RM336, RM9 and RM20 were used for study (Table 1).

The total volume of PCR cocktail for this study was $13 \mu 1$ per sample. It contained $1 \mu 1$ 10x PCR buffer, $1 \mu 1 \mathrm{dNTPs}, 1.5 \mu 1$ primer forward, $1.5 \mu 1$ primer reverse, $0.2 \mu 1$ Taq polymerase and $2.8 \mu 1$ sterile $\mathrm{dH}_{2} \mathrm{O}$. Two $\mu 1$ genomic DNA was added with $8 \mu$ PCR cocktail. Template DNA was initial ly denatured at $94^{\circ} \mathrm{C}$ for 3 minutes followed by 34 cycles of PCR amplification with the thermal profile of 30 seconds denaturation at $95{ }^{\circ} \mathrm{C}$, 1 minute primer annealing at $55^{\circ} \mathrm{C}$ and 30 seconds primers extension at $72{ }^{\circ} \mathrm{C}$. Finally, 7 minutes incubation at $72^{\circ} \mathrm{C}$ was allowed for completion of primer extension. For checking amplification, the PCR products were electrophoretically resolved on $1 \%$ agarose gel in $0.5 \mathrm{X}$ TBE.

The level of polymorphism among the 10 rice germplasm was evaluated by calculating allele numbers and polymorphic information content (PIC) values for each of the three SSR loci. PIC or expected heterozygosity for each SSR marker was calculated based on the formula $\mathrm{Hn}=1-\sum \mathrm{p}_{\mathrm{i}}^{2}$, where $\mathrm{p}_{\mathrm{i}}$ is the allele frequency for the i-th allele.

\subsubsection{Polyacrylamide gel electrophoresis for microsatellite analysis}

Before sample loading, both the gel and PCR products were preheated. During preheating of gel, the comb was again placed on the gel allowing sample to be loaded easily and $1200 \mathrm{ml} 1 \mathrm{x}$ TBE buffer was added to the vertical chamber. The gel was pre-run for 30 minutes at $120 \mathrm{~W}$ to rise the temperature up to $50^{\circ} \mathrm{C}$. Meanwhile, PCR-products and $5 \mu 1100 \mathrm{bp}$ DNA ladder were preheated at $95{ }^{\circ} \mathrm{C}$ for 5 minutes. After electrophoresis the gel was stained with silver nitrate. The individual bands in

\begin{tabular}{|c|c|c|c|c|c|}
\hline $\begin{array}{l}\text { Primer } \\
\text { name }\end{array}$ & $\begin{array}{l}\text { Size } \\
\text { range } \\
\text { (bp) }\end{array}$ & $\begin{array}{l}\text { Chro- } \\
\text { mosome } \\
\text { locus }\end{array}$ & & equence & $\begin{array}{l}\text { Annealing } \\
\text { temp. }\left({ }^{\circ} \mathrm{C}\right)\end{array}$ \\
\hline \multirow[t]{2}{*}{ RM231 } & $169-191$ & 3 & Fwd. & $\begin{array}{l}\text { ccagatt- } \\
\text { atttcetgag- } \\
\text { gtc }\end{array}$ & 55 \\
\hline & & & Rev. & $\begin{array}{l}\text { cacttg- } \\
\text { catagttctg- } \\
\text { cattg }\end{array}$ & \\
\hline \multirow[t]{2}{*}{ RM24 } & $152-198$ & 1 & Fwd. & $\begin{array}{l}\text { gaagtgt- } \\
\text { gatcactg- } \\
\text { taacc }\end{array}$ & 55 \\
\hline & & & Rev. & $\begin{array}{l}\text { tacagtg- } \\
\text { gacggc- } \\
\text { gaagtcg }\end{array}$ & \\
\hline \multirow[t]{2}{*}{ RM336 } & $148-193$ & 7 & Fwd. & $\begin{array}{l}\text { cttacaga- } \\
\text { gaaacg- } \\
\text { gcatcg }\end{array}$ & 55 \\
\hline & & & Rev. & $\begin{array}{l}\text { gctggttt- } \\
\text { gtttcaggt- } \\
\text { tcg }\end{array}$ & \\
\hline \multirow[t]{2}{*}{ RM9 } & $124-194$ & 1 & Fwd. & $\begin{array}{l}\text { acggecct- } \\
\text { catcaccttc }\end{array}$ & 55 \\
\hline & & & Rev. & $\begin{array}{l}\text { ggtgccat- } \\
\text { tgtcctc }\end{array}$ & \\
\hline \multirow[t]{2}{*}{ RM20 } & $162-198$ & 12 & Fwd. & $\begin{array}{l}\text { atcttgtc- } \\
\text { cctgcag- } \\
\text { gtcat }\end{array}$ & 55 \\
\hline & & & Rev. & $\begin{array}{l}\text { gaaaca- } \\
\text { gaggca- } \\
\text { catttcattg }\end{array}$ & \\
\hline
\end{tabular}

glass plate were stained and scored for analysis.

\subsubsection{Microsatellite data analysis}

Only clear and unambiguous SSR markers were scored to the presence and absence of the corresponding band among the genotypes. The scores 1 and 0 indicated the presence and absence of bands, respectively. The unweighted pair-group method with arithmetic means (UPGMA) dendrogram was drawn by using the software TREEVIEW. Nei's (1972) genetic distance value was computed using the POPGENE (Version 1.31) software user manual.

\subsection{RAPD analysis}

2.3.1. Reaction mixture preparation, amplification and electrophoresis

DNA samples were quantified by the spectrophotometer and 
the concentration adjusted to $25 \mathrm{ng} \mu^{-1}$. Each RAPD reaction was done with $10 \mu \mathrm{l}$ containing 10X PCR Buffer $1 \mu \mathrm{l}, 1 \mu \mathrm{l}$ dNTP, Taq polymerase $1 \mu \mathrm{l}$, and distilled water $3.3 \mu$ l. DNA amplification was performed in an oil-free thermal cycler with the following programme: preheat at $94{ }^{\circ} \mathrm{C}$ for 3 minutes followed by 40 cycles of $1 \mathrm{~min}$ denaturation at $94{ }^{\circ} \mathrm{C}, 1 \mathrm{~min}$ annealing at $34^{\circ} \mathrm{C}$ and extension at $72^{\circ} \mathrm{C}$ for 2 minutes. After the last cycle, a final step was for 7 minutes at $72{ }^{\circ} \mathrm{C}$ to allow complete extension of all amplified fragments and reactions were held at $4{ }^{\circ} \mathrm{C}$. The amplified products were separated by electrophoresis in $1.5 \%$ agarose in $1 \mathrm{x}$ TBE buffer, containing $2.50 \%$ ethidium bromide at $100 \mathrm{~V}$ for $1 \mathrm{hr}$. The gels were visualized under UV light and the images were transferred to a microcomputer for analysis.

\subsubsection{RAPD data analysis}

The amplified bands were visually scored as present (1) and absent (0) separately for each individual and each primer. The scores obtained were pooled to create a single data matrix. This was used to estimate polymorphic loci, Nei's (1973) gene diversity, genetic distance (D) and a UPGMA dendrogram using a computer programme, POPGENE (Version 1.31) (Yeh et al., 1999). The same programme was also used to perform test of homogeneity in different locus between population pairs. Genetic similarity was determined according to the following formula:

Similarity index $(\mathrm{SI})=2 \mathrm{~N}_{\mathrm{xy}} / \mathrm{N}_{\mathrm{x}}+\mathrm{N}_{\mathrm{y}}$

Where, $\mathrm{N}_{\mathrm{xy}}$ is the number of RAPD bands shared by individuals $\mathrm{x}$ and $\mathrm{y}$ respectively, and $\mathrm{Nx}$ and $\mathrm{N}_{\mathrm{y}}$ are the number of bands in individual $\mathrm{x}$ and $\mathrm{y}$, respectively (Chapco et al., 1992).

\section{Results and Discussion}

\subsection{Phenotypic performance of twenty rice germplasm}

Variation in phenotypic performance was found among studied 20 rice germplasm in respect to yield and yield components (Table 2). It was observed that HYV(s) showed comparatively shorter plant height than local varieties. Among local varieties, Jongli Boro showed highest plant height $(177.37 \mathrm{~cm})$ than other local varieties and HYVs. Both RD-2586 and Kalo Bhog flowered earlier (72 days). RD-2586 matured at earliest (101 days) time. BINA Dhan-6, BINA Dhan-5 and Binashail gave higher grain yield plant ${ }^{-1}(39.82 \mathrm{~g}, 37.70 \mathrm{~g}$ and $35.89 \mathrm{~g}$, respectively). Thousand grain weight of BINA Dhan- 4 was the highest (26.89 g) among all germplasm. BINA Dhan-6 showed the highest number of effective tillers hill-1 ${ }^{-1}$ (1) and the highest

\begin{tabular}{lccccccc}
\hline \multicolumn{7}{l}{ Table 2: Performance of yield and yield components of 20 rice germplasm } \\
\hline $\begin{array}{l}\text { Strain/ } \\
\text { Variety }\end{array}$ & $\begin{array}{c}\text { Plant } \\
\text { height }(\mathrm{cm})\end{array}$ & $\begin{array}{c}\text { Days to } \\
\text { flowering }\end{array}$ & $\begin{array}{c}\text { Days to } \\
\text { maturity }\end{array}$ & $\begin{array}{c}\text { Efective } \\
\text { tillers hill }\end{array}$ & $\begin{array}{c}\text { No. of grains } \\
\text { panicle }^{-1}\end{array}$ & $\begin{array}{c}\text { 1000-grain } \\
\text { wt. }(\mathrm{g})\end{array}$ & $\begin{array}{c}\text { Grain yield } \\
\text { plant }^{-1}(\mathrm{~g})\end{array}$ \\
\hline Iratom-24 & 89.30 & 100 & 125 & 10 & 115 & 22.25 & 30.21 \\
Binashail & 148.40 & 104 & 132 & 7 & 216 & 24.21 & 35.89 \\
BINA Dhan-4 & 130.60 & 93 & 125 & 7 & 176 & 26.89 & 31.88 \\
BINA Dhan-5 & 102.30 & 112 & 140 & 9 & 236 & 25.12 & 37.70 \\
BINA Dhan-6 & 110.10 & 115 & 142 & 11 & 252 & 23.02 & 39.82 \\
RD-2586 & 108.63 & 72 & 101 & 9 & 90 & 22.30 & 18.28 \\
Y-1281 & 95.25 & 97 & 126 & 9 & 238 & 20.21 & 32.19 \\
TNDB-100 & 93.98 & 90 & 122 & 10 & 180 & 21.02 & 27.21 \\
BRRI Dhan 32 & 123.60 & 96 & 119 & 7 & 168 & 18.03 & 26.67 \\
BRRI Dhan 36 & 104.72 & 109 & 130 & 9 & 128 & 21.42 & 23.92 \\
BRRI Dhan 37 & 132.61 & 98 & 129 & 9 & 250 & 15.89 & 24.32 \\
BRRI Dhan 38 & 132.30 & 96 & 129 & 6 & 210 & 16.42 & 23.02 \\
BRRI Dhan 40 & 143.30 & 109 & 136 & 8 & 219 & 24.36 & 26.09 \\
BRRI Dhan 41 & 163.10 & 106 & 135 & 6 & 191 & 23.12 & 22.12 \\
Chini Shagor & 146.30 & 85 & 122 & 7 & 104 & 15.20 & 18.19 \\
Baowi Jhak & 162.40 & 86 & 125 & 6 & 112 & 13.22 & 17.18 \\
Jongli Boro 581 & 177.37 & 86 & 119 & 8 & 96 & 20.20 & 16.18 \\
Kalo Bhog & 144.51 & 72 & 120 & 6 & 152 & 15.09 & 16.01 \\
Kala Jira & 144.09 & 95 & 125 & 9 & 80 & 14.14 & 12.16 \\
Dhol Kochuri & 165.39 & 100 & 130 & 6 & 102 & 20.22 & 10.12 \\
CV (\%) & 20.20 & 12.35 & 7.03 & 19.77 & 35.52 & 19.87 & 34.34 \\
\hline
\end{tabular}


number of grains per panicle (252) which ultimately produced higher grain yield plant ${ }^{-1}$.

\subsection{Genotypic performance of 20 rice germplasm with SSR}

All microsatellite primers showed polymorphism among 20 rice germplasms. Thirty three bands were scored from five SSR markers. The marker RM231 showed six alleles in 20 rice germplasm (Figure 1).

The number of alleles ranged from lowest five to highest eight per locus. The average numbers of alleles was 6.6. RM24 and RM336 had the highest number of alleles (8) compared to primers RM231 (6), RM9 (5) and RM20 (6). Saker et al. (2005) observed that the six SSR primer sets which were distributed through six different rice chromosomes revealing 25 alleles, eight alleles with RM-10 primer set, six with T92, five alleles with RM13 primer set, four alleles to each RM-8 and two with RM-3 and RM-14 primer sets.

The average PIC value of SSR marker was 0.789 and ranged from 0.832 (RM336) to 0.741 (RM9) (Table 3). The highest PIC value was observed in RM336, while lowest in RM9. Ravi et al., 2003 reported the average PIC value 0.578 and it ranged from a low of zero (RM115) to a high of 0.890 (RM202) for 38 SSR markers in 40 rice cultivars.

\subsection{Dendrogram}

Twenty germplasm used to make dendrogram based on Nei's (1972) genetic distance using UPGMA were differentiated

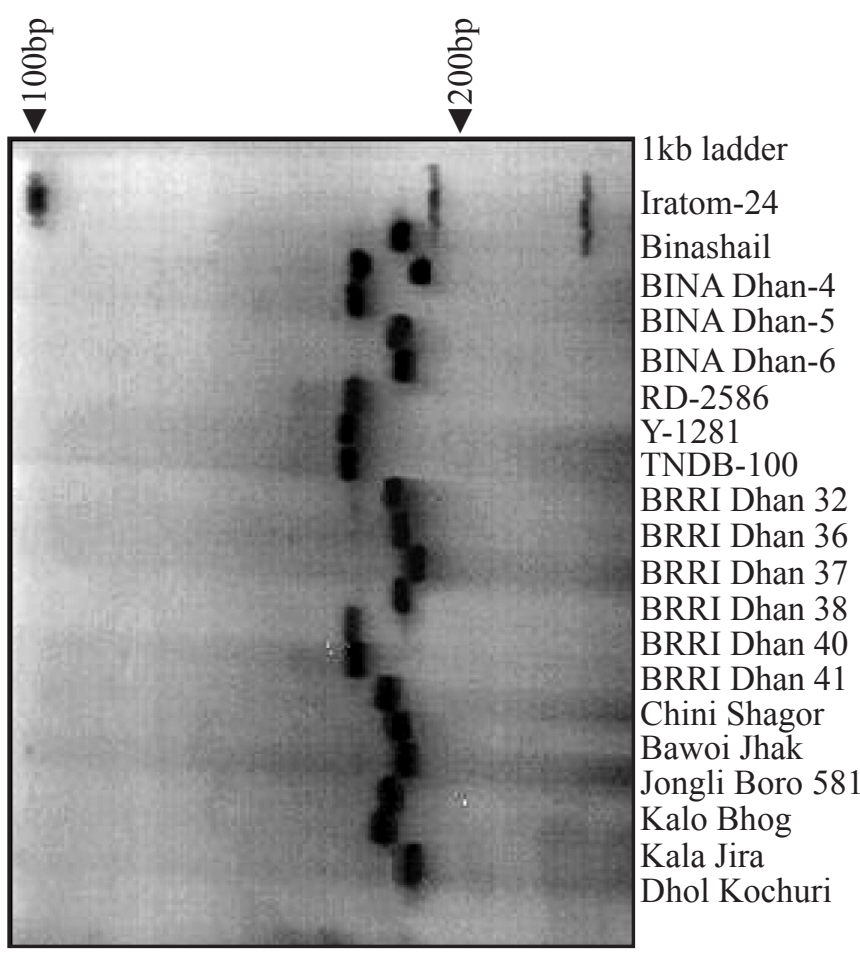

Figure 1: Microsatellite profiles of 20 rice germplasm at loci RM231 into three main clusters; Binadhan-5, Binadhan-6, Iratom-24, BRRI Dhan 37 and BRRI Dhan 36 were grouped in cluster 1 (Figure 2). The germplasms TNDB-100, Binashail, Chini Shagor, BRRI Dhan 41, RD-2586, Jongli Boro, BRRI Dhan40 and Kalo Bhog formed cluster 2 and Dhol Kochuri, BINA Dhan-4, BRRI Dhan 38, Y-1281, Bawoi Jhak, BRRI Dhan 32 and Kala Jira formed cluster 3.

In cluster 1, BRRI Dhan 36 alone grouped in a sub cluster and Iratom-24, BRRI Dhan 37 and BINA Dhan-5, BINA Dhan 6 grouped in two different sub cluster. In cluster 2, TNDB-100 alone grouped in sub-cluster I. Sub-cluster II was divided into two sub clusters. Binashail, Chini Shagor, BRRI Dhan 41, RD-2586 and Jongli Boro 581 were grouped in a sub-cluster of sub-cluster II where RD-2586 and Jongli Boro 581 were grouped in sub-sub-cluster. BRRI Dhan 40 and Kalo Bhog were grouped in another sub-cluster of sub-cluster II. In cluster 3, Dhol Kochuri, BINA Dhan-4, BRRI Dhan 38, Y-1281 and Bawoi Jhak were grouped in a sub-cluster while BINA Dhan-4 and BRRI Dhan 38 were grouped in a sub-sub-cluster. BRRI Dhan 32 and Kala jira were grouped in another sub-cluster of cluster 3 . The rice genotypes were classified and grouped into 11 distinct groups (Chakravarti et al., 2006); Yu et al. (2004) studied cluster analysis of the 223 accessions parental lines of rice and showed three major groups and nine sub groups. The dendrogram revealed that the genotypes derived fro genetically similar type clustered together.

In a sub cluster of cluster 1: Binadhan-5, Binadhan-6, Iratom24 and BRRI Dhan 37 are grouped in same sub-cluster and Binadhan-5, Binadhan-6 and BRRI Dhan 37 showed comparatively similar performance based on phenotypic characters like plant height, number of effective tillers hill ${ }^{-1}$ and number of grains panicle ${ }^{-1}$ (Table 2). It is noted that, $F_{2}$ seeds from Iratom-24x Dular were irradiated and 2 high yielding sister lines were identified as Binadhan-5 and Binadhan- 6 indicating similar agronomic performance between these two varieties. In cluster 2, TNDB-100 alone grouped in a sub cluster may be due to mutant variety. RD-2586 and Jongli Boro were

Table 3: Status of microsatellite markers towards genetic diversity of 20 rice genotype

\begin{tabular}{lccccc}
\hline $\begin{array}{l}\text { Primer } \\
\text { name }\end{array}$ & $\begin{array}{c}\text { Chro- } \\
\text { mo- } \\
\text { some } \\
\text { locus }\end{array}$ & $\begin{array}{c}\text { Size } \\
\text { range } \\
\text { (bp) }\end{array}$ & $\begin{array}{c}\text { No. of } \\
\text { alleles }\end{array}$ & $\begin{array}{c}\text { Diversity } \\
\text { index } \\
\text { PIC }= \\
1-\sum \mathrm{Xi} 2 \mathrm{j}\end{array}$ & $\begin{array}{c}\text { Avg. PIC } \\
\text { value }\end{array}$ \\
\hline RM231 & 3 & $169-191$ & 6 & 0.809 & 0.789 \\
RM24 & 1 & $152-198$ & 8 & 0.749 & \\
RM336 & 7 & $148-193$ & 8 & 0.832 & \\
RM9 & 1 & $124-194$ & 5 & 0.741 & \\
RM20 & 12 & $162-198$ & 6 & 0.813 & \\
\hline
\end{tabular}


introduced from different countries but were grouped together with close genetic distance $(0.00)$. But phenotypically they showed differences (Table 2). Same cases were also observed in some HYVs and Landraces like Binashail vs. Chini Shagor, BRRI Dhan 40 vs. Kalo Bhog. Actually these germplasm are different, although they showed close genetic distance. The reason might be use of only five SSR primers for genomic coverage.

BINA Dhan-4 and BRRI Dhan 38 have been grouped in same sub-sub cluster in cluster 3 and their phenotypical characteristics of plant height, days to maturity; grain character and yield were similar. Dhol Kochuri alone was in different sub cluster and it is a landrace with different phenotypical characteristics. A subset of three rice groups were analyzed by using 19 SSR loci and 12 inter-SSR-PCR primers indicating that the subset of aromatic rice varieties is probably derived from a single landrace (Nagaraju et al., 2002).

The highest genetic distance was 2.8904 from Summary of Nei's (1972) genetic distance (below diagonal) values for different cultivar pairs of rice (Figure 2). between Kala Jira vs. Iratom-24, BINA Dhan-5, BINA Dhan-6, because of Kala Jira is a local variety and others are mutant variety. So, kala Jira was located in a distinct position in the dendrogram from those germplasms.

\subsection{Genotypic performance of twenty rice germplasm with RAPD markers}

Thirty three distinct bands were scored from selected five primers and thirty one bands were considered as polymorphic (93.80\%). Maximum numbers of polymorphic bands (9) were generated from OPA02 suggested high level of polymorphism

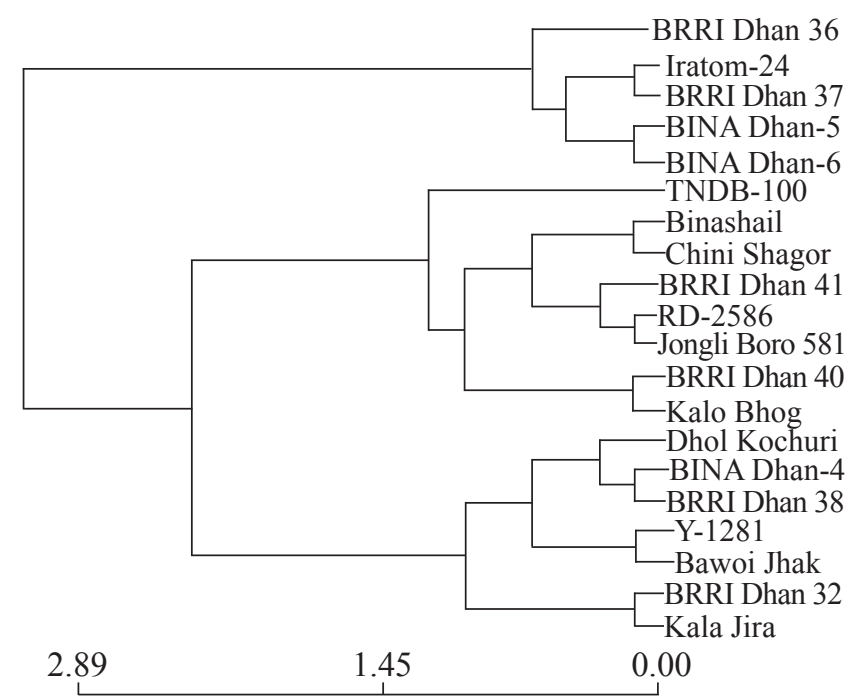

Figure 2: UPGMA dendrogram based on Nei's (1972) genetic distance showing differentiation of 20 rice germplasm according to SSR
(Table 4).

The RAPD band profiles of primer OPA01 with 6 varieties are shown in (Figure 3).

\subsection{UPGMA dendrogram}

The unweighted pair group method of arithmatic means (UPGMA) dendrogram was constructed based on Nei's (1972) original measures of genetic distance (D) (Figure 4). In this study 20 rice germplasms were grouped into three clusters; BRRI Dhan 37, Iratom-24, BRRI Dhan 36, Binashail, RD2586, BRRI Dhan 32, TNDB-100, BRRI Dhan 40 and Kala Jira grouped in cluster 1. BRRI Dhan 38, BRRI Dhan 41, Chini Shagor, Baowi Jhak and Kalo Bhog were grouped in cluster 2 and in cluster 3 there were Jongli Boro 581, BINA Dhan-4, BINA Dhan-5, BINA Dhan-6, Y-1281 and Dhol Kochuri. Cluster 1 was divided into two sub-clusters. Sub-cluster I have several sub-sub-clusters and main sub-cluster I have BRRI Dhan 37, Iratom-24, Binashail, BRRI Dhan 32, BRRI Dhan 40 and Kala Jira with sub-sub-clusters variation. Cluster 2

Table 4: Sequence, number of bands and percentage of polymorphic loci across primers in rice germplasm

\begin{tabular}{|c|c|c|c|c|c|}
\hline $\begin{array}{l}\text { Primer } \\
\text { code }\end{array}$ & $\begin{array}{c}\text { Sequences } \\
(5 /-3 /)\end{array}$ & $\begin{array}{l}\text { Total } \\
\text { no. of } \\
\text { band } \\
\text { scored }\end{array}$ & $\begin{array}{l}\text { Poly- } \\
\text { mor- } \\
\text { phic } \\
\text { bands }\end{array}$ & $\begin{array}{l}\text { Poly- } \\
\text { mor- } \\
\text { phism } \\
(\%)\end{array}$ & $\begin{array}{l}\text { Mean } \\
\text { poly- } \\
\text { mor- } \\
\text { phism }\end{array}$ \\
\hline OPA01 & $\begin{array}{l}\text { CAGGC- } \\
\text { CCTTC }\end{array}$ & 6 & 6 & 100 & 93.80 \\
\hline OPA02 & $\begin{array}{c}\text { TGC- } \\
\text { CGAGCTG }\end{array}$ & 9 & 9 & 100 & \\
\hline OPB01 & GTTTCGCTCC & 5 & 5 & 100 & \\
\hline OPB02 & $\begin{array}{c}\text { TGATCCCT- } \\
\text { GG }\end{array}$ & 6 & 5 & 83.33 & \\
\hline OPB07 & $\begin{array}{c}\text { GGTGACG- } \\
\text { CAG }\end{array}$ & 7 & 6 & 85.71 & \\
\hline Total & & 33 & 31 & & \\
\hline
\end{tabular}

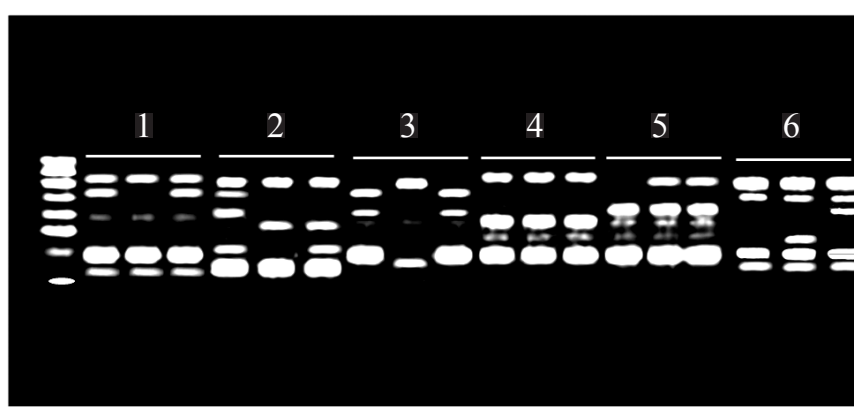

Figure 3: 1: Iratom-24; 2: Binashail; 3: BINA Dhan-4; 4: BINA Dhan-5; 5: BINA Dhan-6; 6: RD-2586; RAPD profiles of six rice germplasms at loci OPA01 


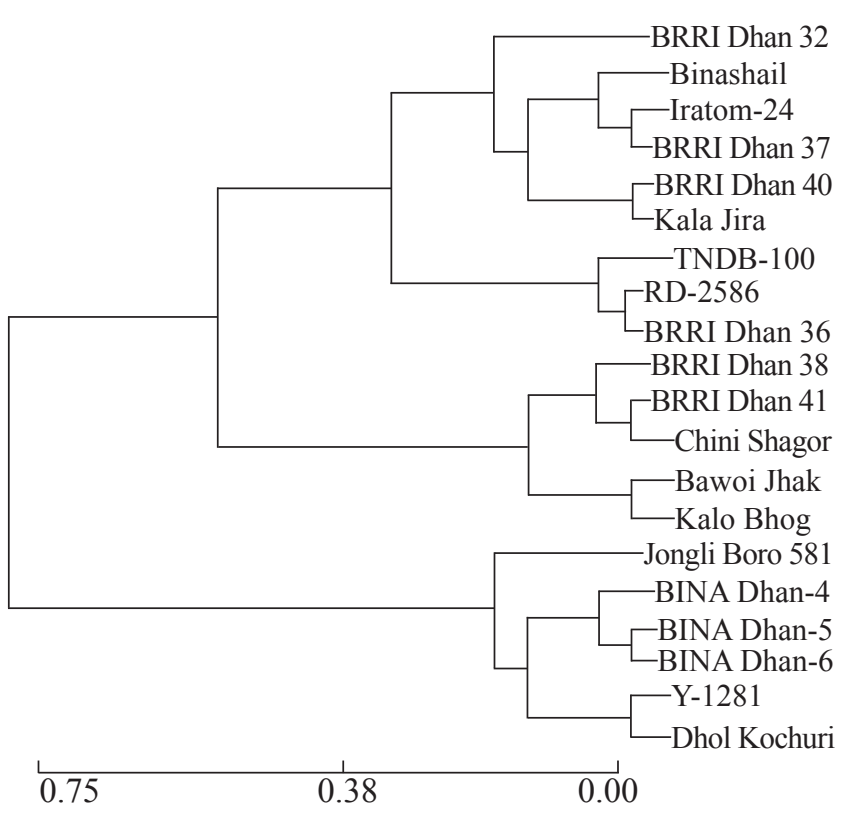

Figure 4: UPGMA dendrogram based on Nei's (1972) original measures of genetic distance, summarizing the data on differentiation between rice germplasm according to RAPD analysis

have two sub-clusters, sub-clusters I and sub-clusters II. Subclusters I have divided into sub-sub cultures. BRRI Dhan 38, BRRI Dhan 41 and Chini Shagor were grouped in sub cluster. In another sub-cluster there were Baowi Jhak and Kalo Bhog. Cluster 3 was divided into two sub-clusters. Jongli Boro 581 alone was grouped in one sub-cluster and BINA Dhan-4, BINA Dhan-5, BINA Dhan-6, Y-1281, Dhol Kochuri were grouped in another sub-cluster where BINA Dhan-5 and BINA Dhan-6 were grouped in a sub-sub-cluster. BINA Dhan-5 and TNDB100 were distinctly located in the dendrogram which supports with highest genetic distance (0.7504) in between them. In cluster 2, BINA Dhan-5 and BINA Dhan-6 were grouped in same sub-cluster and also showed lowest genetic distance $(0.0441)$ between them.

\subsection{Comparison of SSR and RAPD markers}

In the present study average polymorphism percentages of SSR (100\%) is relatively higher than RAPD (93.80\%) across primers (Table 5). Shannon's information index from SSR is higher (1.69) than that of RAPD (0.52). Higher polymorphism and Shannon's information index across primers indicate the superiority of the SSR marker than RAPD in rice diversity analysis.

Table 5: Comparative average polymorphism and Shannon's information index value of

\begin{tabular}{lll}
\hline SSR and RAPD & Polymorphism \% & Shannon's inf. index \\
\hline SSR & 100 & 1.69 \\
RAPD & 93.80 & 0.52 \\
\hline
\end{tabular}

In genetic diversity analysis both SSR and RAPD markers helped in grouping the genotypes according to their subspecies level. The SSR markers grouped fewer genotypes in subclusters of a cluster while the RAPD markers grouped more genotypes in sub-clusters of a cluster and therefore more variation within each cluster. Between the DNA markers, SSR markers were more polymorphic and specific. The polyallelic nature of SSR markers has the advantage of discriminating the individuals more precisely (Ravi et al., 2003).

From the present study it is clear that unique SSR profiles can give more clear relationship and genetic diversity among rice genotypes than RAPD. Xiao et al. (1996) found that the comparison of RAPD and SSR markers profiles of different genotype pairs that tend to cluster together revealed more discriminating power of SSR markers than RAPD markers. Moreover varietal profiling based on SSR markers will be more reliable than the profiling based on RAPD markers and there are possibilities for cost reduction when SSR markers are used; SSR marker analysis based on the availability of more than 2500 SSR loci convening the entire rice genome (McCouch et al., 2002) augmented with silver staining, multiplex PCR and multiplex PAGE can remain as the future viable strategy for the marker based varietal profiling in rice and extending the same to the purity analysis. The polyallelic nature of SSR markers has the advantage of discriminating the individuals more precisely.

\section{Conclusion}

DNA fingerprinting is a useful tool for varietal protection to prove ownership or derivation of plant lines where SSR markers have been proved to be powerful tools for molecular genetic diversity analysis of rice cultivars for plant breeding programme to produce new varieties that are aimed towards the improvement of crop productivity and able to withstand from biotic and abiotic factors.

\section{References}

Becker, J.P.V., Kuiper, M., Salamini, F., Heun, M., 1995. Combined mapping of AFLP and RFLP markers in barley. Molecular and General Genetics 249, 65-73.

Blair, M.W., Panaud, O., McCouch, S.R., 1999. Inter-simple sequence repeat (ISSR) amplification for analysis of microsatellite motif frequency and fingerprinting in rice (Oryza sativa L.). Theoretical and Applied Genetics 98, 780-792.

Brown, S.M., Kresovich, S., 1996. Molecular characterization for plant genetic resources conservation. In: A.H. Paterson (ed.), Genome Mapping in Plants. New York. R.G. Landes Company, p. 85-93.

Chakravarthi, B.K., Naravaneni, R., 2006. SSR marker based 
DNA fingerprinting and diversity study in rice (Oryza sativa L.). African Journal of Biotechnology 5 (9), 684688.

Chapco, W., Ashton, N.W., Martel, R.K., Antonishishyn, N., Crosby, W.L., 1992. A feasibility study of the use of random amplified polymorphic DNA in the population genetics and systematic of grasshoppers. Genome 35, 569-574.

IRRI (International Rice Research Institute). 1997. Rice Almanac. IRRI-WARDA-CIAT, Los Banos, Laguna, Philippines.

Joshi, S.P., Gupta, V.S., Aggarwal, R.K., Ranjekar, P.K., Brar, D.S., 2000. Genetic diversity and phylogenetic relationship as revealed by Inter simple sequence repeat polymorphism in the genus Oryza. Theoretical and Applied Genetics 100, 1311-1320.

Levinson, G., Gutman, G.A., 1987. Slipped-strand mispairing: a major mechanism of DNA sequence evolution. Molecular Biology and Evolution 4, 203-221.

McCouch, S.R., Temnykh, S., Xn, Y., Lobor, K.B., Clane, K., Walton, M., Maghirang, B. Fu. R., Xing, Z. Li, Y., Zhang, Q., Kono, I., Yamo, M., Fjellstron, R., Declerck, G., Stein., 2002. Development and mapping of 2240 new SSR markers for rice. DNA Research 9, 257-279.

Nagaraju, J., Kathirve, M., Ramesh, R.K., Siddiq, E.A. Hasnain, E., 2002. Genetic analysis of traditional and evolved Basmati and non-Basmati rice varieties by using fluorescence-based ISSR-PCR and SSR markers. Agriculture Science 99(9), 5836-5841.

Nei, M., 1972. Genetic distance between populations. American. Naturalist 106, 283-292.

Nei, M., Roychoudhury, A.K., 1973. Probability of an overdominant mutation. Genetics 74, 371-380.
Ravi, M., Geetanjali, S., Sameeyafarheen, F., Maheswaran, M., 2003. Molecular marker based genetic diversity analysis in rice (Oryza sativa L.) using RAPD and SSR markers. Euphytica 133, 243-252.

Saker, M.M., Sawsan, S., Youssef, Naglaa, A., Abdallah, Hany, S., Bashandy, M., Ahmed, E., Sharkawy, 2005. Genetic analysis of some Egyptian rice genotypes using RAPD, SSR and AFLP. African Journal of Biotechnology 4(9), 882-890.

Weir, B.S., 1990. Genetic Data Analysis: Methods for Discrete Population Genetic Data. Sinauer Associates, Inc. Publishers. Sunderland, Massachusetts 377.

Williams, J.G.K., Kubelik, A.R., Livak, K.J., Rafalski, J.A., Tingey, S.V., 1990. DNA polymorphisms amplified by arbitrary primers are useful as genetic markers. Nucleic Acids Research 18, 6531-6535.

Xiao, J., Yuan, J.Li.L., McCouch, S.R., Tankskey, S.D., 1996. Genetic diversity and its relationship to hybrid performance and heterosis in rice as revalved by PCR based markers. Theoretical and Applied Genetics 92, 637-643.

Yeh, F.C., Yang, R.C., Boyle, T.B.J., Ye, Z.H., Mao, J.X., 1999. POPGENE, the user-friendly shareware for population genetic analysis. Molecular Biology and Biotechnology Centre, University of Alberta, Canada.

Yu, P., Li, Z., Zhang, H., Hurst, L.D., Wang, M., Sun, J., Wang, X., 2004. Genetic diversity of common wild rice (Oryza rufipogon Griff) by using SSR markers and phenotypic traits in Guangxi Province. Yi Chuan Xue Bao 31(9), 934-40.

Zhu, J., Gale, M.D., Quarrie, S., Jackson, M.T., Bryan, G.J., 1998. AELP markers for the study of rice biodiversity. Theoretical and Applied Genetics 96, 602-611. 